\title{
Deconstruction of Dictatorship in Jorge Mario Pedro Vargas Llosa's Works
}

\author{
Nasrin Haghighat Chaleshtari \& Ali Omidi \\ n.haghighat@fgn.ui.ac.ir \& aliomidi@ase.ui.ac.ir \\ Faculty of Foreign Languages \& Faculty of Administrative Sciences and Economics, \\ University of Isfahan, IRAN
}

\begin{abstract}
Latin America's literature does not merely represent the creation of literary masterpieces for artistic enjoyment; instead, it is inspired by real-world events. Latin American authors attempt to depict the pains, sufferings, and problems they have always grappled with. Taking a descriptive-analytic approach by applying sociological criticism, the present study attempted to examine Jorge Mario Pedro Vargas Llosa's most essential works on dictatorship rule, including Conversación en La Catedral, La guerra del fin del mundo, La ciudad y los perrosand La fiesta del chivo. One of the Latin America's political typical features was fascism and dictatorship, which was reflected in different authors' works, including Llosa. The findings of the present study revealed that the dictatorial system raised in Llosa's works is characterized by violence, political and economic corruption, intervention by foreign powers, the emergence of Communism as the sole savior of the third world, and the elites' disenchantment with improvement in the status of the society. He put forward this sober idea that dictators are not natural catastrophes, but they are constructed as dictators by their victims.
\end{abstract}

Article

information

Received: 26 June 2020

Revised: 25 September 2020

Accepted: 19 October 2020

Keywords: Political literature; Latin America; Boom; sociological criticism

\section{Introduction}

Most of the Latin American writers turn the familiar themes and events of their societies into novels. For this reason, their literary works have been unique and identified as a specific style known as the Latin American style. Jorg Mario Pedro Vargas Llosa is one of South America's most significant contemporary novelists, born on March 28, 1936, in Peru.
When he was 14, his father sent him to Army School, which greatly influenced him. In the Novel La ciudad y los perros, published in 1963, he illustrated his experience of years of living in Army school. He attempted to manifest the violence and corrupted conditions he experienced when he was very young in that novel. The Novel, La ciudad y los perros, which reflects his hard days in the army school, paved his way to fame. Generally speaking, the golden age of Latin America's literature called "Boom" 
started from the 1950s and 1960s, attracting the world's attention to this continent and its literature. In this period, besides Llosa, such great writers as Gabriel Garcia Marquez (19582014), Carlos Fuentes (1954-2012), and Julia Cortazar (1914-1984) also stand out. Although all the Boom writers pivoted their work on the revelation of the living conditions of aboriginals of Latin America and shedding light on the oppressions they lived through, the works of Llosa do not just subscribe to magical realism, the style often considered synonymous with Boom and extended to the style of the entire typical writers of this era. Unlike Marquez, Llosa does not mix reality with magic. Of course, his works are blended with imagination, but the reality-driven aspects prevail. Even for writing the stories, he makes use of real characters so that the genius of the writer is combined with the accuracy of the events that he has witnessed. Marcus-Delgado $(2004,132)$ maintains Llosa is of the opinion that there is an interaction between literature, politics, politicians, and writers, and his works are not apart from it. In other words, he uses accurate and detailed documentation in the same way that he employs his prolific imagination. This means he mixes reality with innovation to reconstruct the past; he manipulates time with particular creativity to provoke the imagination of the readers because he believes, "it is easier to invent, to produce persuasive fiction if it has the appearance of being realistic" (Llosa 1991, 110).

As well as enjoying the dramatic aspects of writing style, Llosa's works reflect the political circumstances of the society. He appreciates Jean-Paul Sartre's ideas that "literature is not and cannot be gratuitous, that it is unacceptable for literature to be purely entertainment" (Llosa 1991, 49). In his opinion, a good story can bridge the gap between the story and the readers, which is called "the double spectator" by Gorham $(2005,269)$. In this regard, literature improves life and fills the gaps through creativity and innovation. Writing is a kind of freedom of expression. Literature should be politically, socially, and aesthetically loaded. Llosa also states that we can say literature is seditious since it raises the readers' awareness of dishonesty and shortcomings. Still, it does not mean that "literary text will provoke immediate social upheaval or accelerate revolutions. The social and political effect of a poem, a play, or a novel cannot be foreseen, because they are not collectively made or collectively experienced" (Llosa 2001b). In his opinion, it's challenging for a Latin American writer to avoid politics. "Literature is an expression of life, and you cannot eradicate politics from life" (The New York Times, 2010).

Llosa was a prominent public intellectual of the Left in the 1960s. Later on, he was inclined to liberal values and associated with people such as Isaiah Berlin. He was initially an enthusiastic fan of the Cuban revolutionary government of Fidel Castro and the Communist Party of Peru - Shining Path. Still, he later became disenchanted with their policies, particularly after the imprisonment of Cuban poet Heberto Padilla in 1971, and then became Castro critics. In "Sabers and Utopias," he doesn't distinguish between left and right authoritarian leaders such as Hugo Chávez in Venezuela, Gen. Augusto Pinochet in Chile and the Peronist military dictatorship in Argentina. In 1990, he ran for President of Peru as the candidate of the Right; finally, the very first time after being defeated in the election by Alberto Fujimori, he left Peru for good and has focused on writing. In 2010, the Swedish Nobel Academy praised Llosa for portraying "cartography of power structures and his trenchant images of the individual's resistance, revolt, and defeat." After observing Brexit in the UK, he maintains that populism replaced Communism recently, and it "is much more difficult to fight because it's not an ideology, not a system with principles, with ideas that we can refute rationally." He believes that "no country is really vaccinated against demagogy or populism" (The New York Times, 2010).

Authoritarianism is one of the prominent themes of Llosa's works. In Rooda's opinion (1998, 2), dictatorship after the Great War has been the most significant problem of twentieth-century literature in Latin America. The dictatorship system and its semiotics in Llosa's works are among the most critical topics capturing the readers' attention, directing their minds towards such questions as: "what symbols does Llosa attribute to such regimes?" and "what socio-political 
consequences does he suppose for such kind of regimes?" The present study attempts to investigate Llosa's works to find the answers to those questions. It also tried to examine the reflections and implications of dictatorship in the most famous works of Llosa, including Conversación en La Catedral (2005), La ciudad y los perros(1966), La guerra del fin del mundo (2008), La fiesta del chivo (2001), La historia de Mayta (1986), Lituma en los Andes (2007a), El hablador (1989), Travesuras de la niña (2007b) and Quién mató a Palomino Molero? (, 1987).

This research-based on the descriptiveanalytic method by applying sociological criticism. It deals mainly with the social function of literary texts. In this approach, literature is a 'social document' or a 'mirror of society,' By examining it, accurate and objective knowledge of social relations can be obtained. Literature is not only a translation of social reality but can also transform the fact that it has arisen as a result. Or, in other words, literature is both a social product and a social force.

\section{Semiotics of Dictatorship in Llosa's Works}

The influence of military dictatorship on Latin America and Peru can be tracked through studying Llosa's works. Cueto (2012) considered "oppressive reality" and "the voice of truth" as the two main themes of Llosa's work. As a realist author, he writes his stories by drawing inspiration from the real world's actual events. In response to Juanita, the sister of one of the defenders of the Mayta group in La historia de Mayta novel, who asked why he did not fabricate the stories he writes, Llosa answered: "because I'm a realist, in my novels I always try to lie knowing why I do it, I explain. That's who I work for, and I think the only way to write stories is to start with history-with a capital H" (Llosa 1986, 58). Llosa describes dictatorship as an atmosphere that affects all aspects of human life. For this reason, he describes the characteristics of dictatorship through dialogues between the characters of his stories.

Kristal (1988), in the book "Temptation of the Word: The Novels of Mario Vargas Llosa" reviewed the various Llosa's works. He argues that Llosa's Novel has demonstrated the condition of his time. Juan E. De Castro (2014) noticed the evolution of Llosa's political perspectives and reflected them across his Novels. He believes, although Llosa's work has been written in the framework of Boom's literature, his realism distinguishes his Novels from magical realism. Wolff (2006) reviewed the reflection of Trujillo's dictatorship in Latin America's literature, especially in Dominican Republic, among four writers including Marcio Veloz Maggiolo, Andrés L. Mateo, Viriato Sención, and Mario Vargas Llosa. He believes, in practical terms, those authors rewrote the political stands of Trujillo and displayed his dictatorship. In the "Talking Books with Mario Vargas Llosa: A Retrospective" (2020), the usage of literary techniques and political metaphors in the Llosa's word was discussed. The authors of the different sections of the book argue that although Llosa presents the political realities in most of his works, employing literary techniques have dramatized his stories to prevent the audience from abhorring the violence of the politics. Unlike most of the papers and evaluations on Llosa's works, which are relatively concentrated on his one Novel, the authors of the present article have focused on approximately all of his novels. In other words, this procedure could be called a subjectoriented method, in which one specific theme, corruption, for instance, was tracked throughout Llosa's works. The most important signs of dictatorship found in Llosa's works are as follows.

\section{People's Submission and Frustration}

In La fiesta del chivo, Llosa describes the life of Rafael Leonidas Trujillo, the dictator of the Dominican Republic, and the impacts of his ruling. The novel envisaged the Trujillo authoritarian years by keeping Boom tradition with a wide-angle and a zoom lens (Menton $2000,676)$. In this novel, he represents the life of people who have been metamorphosed and do everything to prove their loyalty to Trujillo, the dictator. They may even offer their daughters to the dictator, just like Senator Augustine, who gifted his 14-year-old daughter, Uranita, to him (Llosa 2001a, 63). In La fiesta del chivo, Llosa attempts to reveal 
that due to unfavorable political and financial circumstances of that time, most politicians believed the best solution was empowering a person like Trujillo, who was able to provide security and development for the country. The crucial question is how someone like Trujillo can exercise his power without anyone being able to stand up to him at all (Foley 2008, 12). The answer is that almost all Dominicans presumed him as the savior of the people. He brought an end to Caudillo wars, removed the danger of a renewed Haiti incursion, and employed the elites in the government structure. He also terminated his country's dependency on the United States, which had gained control over Dominica's customs office, affected Dominica's exchange rate stability, and interfered with Dominica's economic affairs. "Unlike Antonio, the ingenuous, boyishly innocent Tavito had been a convinced Trujillista, one of those who thought of the chief as a superior being. They often argued about it because its irritated Antonio when his younger brother repeated, like a refrain, that Trujillo was heaven's gift to the republic" (Llosa 2001, 95). In Conversación en La Catedral, the same optimism toward Odria's dictatorship can be noticed. In Llosa's opinion, under those deplorable circumstances, the people of Peru were convinced that the sole solution for improving the conditions was empowering Odria. As Llosa writes: "well, that's why we started the revolution. The lieutenant said good-humoredly. The chaos is all over now. With the army in charge, everybody will toe the mark. You'll see how things are going to get better under Odria" (Llosa 2005, 47).

However, the readers of La fiesta del chivo clearly understand how Trujillo's proponents turned into his enemies over time. There are two reasons why they changed their minds: the first related to the non-fulfillment of their expectations regarding the improvement in their country's socio-political situation. Instead of improving, however, their country was on the path of collapse and decline. Llosa shows how severely the opponents of Trujillo and his authoritarian regime were oppressed. Making use of his strong network of spies, Trujillo was able to repress his opponents, even those living outside Dominica. Accordingly, Llosa mentions the name of Jose
Almonia as an example. The story is that Almonia published a book entitled "A Satrapy in the Caribbean" and criticized Trujillo in that book. Guatemala's government paid all the costs of publishing the book, and its author moved to Mexico for the rest of his life. Trujillo ordered the head of the army spies to catch and kill Almonia because he had threatened the face of the country in which he was grown up. So, he was shot in Mexico (Llosa 2001a, 73). Almoina's death was an example of the opponents' fate, whose voices are silenced in dictatorial regimes.

The second reason Llosa cites for turning Trujillo's proponents into opponents in La fiesta del chivo was that he hurt many of his close friends. He hurt a lot of people who assisted him one way or another. Therefore, a sense of distrust grew among them, and the people around him were always anxious about being suddenly hurt by him. Consequently, the best option was to kill him. " ... To convince himself that as long as Trujillo lived, he and many other Dominicans would be condemned to this awful queasy sickness of constantly having to lie to themselves and deceive everyone else, of having to be two people in one, a public lie and a private truth that could not be expressed" (Llosa 2001a, 166).

In the Novel Conversación en La Catedral, Llosa illustrates a familiar place, Lima. All over the story, he has made use of his personal experiences. Santiago Zavalla, the protagonist of the story, often called Zavalita, reminisces Llosa's character when he was in his teen years and worked at a newspaper office. Kristal (2011.37) believed the ruin of Santiago's life is equal to destruction, misery, and degradation of Peruvian people. In the novel, a nation's downfall is demonstrated through the ruin of myriad individual destinies. It should be said that the novel was written based on Llosa's personal experiences when he entered a society ruled by General Oderia in the 1950s. Looking at history, one can find that the Novel period is not limited to the years of Oderia's reign because the issues presented in this novel continued until the 1960s and 1970s. In Conversación en La Catedral, Llosa demonstrates how the lives of different classes of people, including ministers, students, journalists, drivers, and even prostitutes, have 
been ruined in Oderia's dictatorial regime. First of all, he deals with the life of Santiago Zavalla, the hero of this story. Santiago is the son of one of the Senators, Don Femin.

Santiago is always displeased with his own family's compromising role and other members of the social class to which he belongs. And for this reason, he decides to go to San Marcos University to continue his studies despite his family's disagreement. San Marcos University was a state university where the poor, rebellious people from lower social classes were enrolled looking to achieve political power. These people found that the best choice under the existing political circumstances was to join Marxism and Communism. While at the university, Santiago joins a secret group. However, because his father's phone line was surveilled, the police became aware of this secret group. He and the other members of the team were arrested. He has released in less than 24 hours thanks to his father's political leverage, but the other members were severely punished and tried in court. Santiago was highly impressed by this event because he believed his father took away the opportunity of becoming a hero from him. Then, he left his father's house and started working for a newspaper to earn a living. This way, he found the opportunity to become familiar with the living conditions of Peru's people and their problems and pains more closely (Castro-Klaren, 1989).

Another important topic of Conversación en La Catedral revolves around the restrictions imposed on political parties' activities to preserve the dictator's interests. This is due to the fact that the military government put social institutions and political parties under pressure and even banned their activities for extending and enhancing the political power. This is the reason behind the proliferation of clandestine and underground parties under dictatorial regimes. These groups find no considerable outcomes in peaceful actions, and consequently, they resort to violence. An example of such groups is the secret circle shaped by Santiago and his classmates. "Aida straighten up immediately on the bench. I say that Odria is a dictator and murdered and I'll say it here, in the street, anywhere ... a dictator who'd risen to power at bayonet point ... had ordered the army to massacre the people of Arequipa and now bewitched and had jailed, deported and tortured so many people that no one even knows how many" (Llosa 2005, 66).

The next significant point is that dictatorial regimes interfere with the elections to achieve their own goals. This interference happens not only through manipulating the results of the election but also through confining the activities of the rival parties. Accordingly, the parties that are supposed to be potential threats are not allowed to participate in the elections. In Conversación en La Catedral, Llosa briefly points to Oderia's interference in the election to preclude his rival's victory: "That was nonsense, Senator Landa said. Montagne never had a chance of winning. He didn't have the money for a good campaign, we control the whole electoral apparatus" (Llosa 2005, 145).

It should be noted that such regimes' adverse effects are so extensive that people have no hope in the possibility of improvement in the situation. Even if the dictator declines, the future is not promising. This fact can be noticed in a conversation between two army officers after the fall of Oderia: "I've been waiting half an hour, you lazy bums, Periquito said. Did you hear the news? A military cabinet, because of the trouble in Arequipa. The Arequipans got Bermodez out. This is the end of Odria. Don't be so happy, Carlitos said. The end of Odria and the beginning of what?" (Llosa 2005, 275). Even at the onset of Oderia's reign, this disappointment is visible. The society's social and political conditions will never change; only the power is transferred from one person to another: "Well, that's why we started the revolution, the lieutenant said good-humoredly. The chaos is all over now. With the army in charge everybody will toe the mark. You'll see how things are going to get better under Odria. Really? Bermudez yawned. People change here, lieutenant, never things “(Llosa 2005, 47).

\section{Systematic Violence}

Violence can be assumed as the most essential feature of dictatorship. In TorresRivas's opinion (1999, 286), Latin American societies have harshly experienced violence in 
their political lives. Llosa's works portray extensive violence on different social levels. The central theme of the Novel, La ciudad y los perros, is violence. The story is about the school students who attempt to team up to defend themselves against the older students who bully the youngsters. Dogs in the story symbolize the senior students. In this novel, the world of dogs is the world of deviation, disrepute, and torture, and the world beyond the school's borders characterizes a freer, more civilized, and more decent world. However, the students eventually would take the bad habits institutionalized in them through violence and manipulation of the real world out of the school environment.

The most crucial point here is that the extreme violence results in widespread fear. According to Montes (2011), "Despite being a normal response to the constant prevailing aggression, it is, nevertheless, a repressed and hidden feeling, for not corresponding to what in the military institution is understood by a true man." Fear can be used as a weapon for the people who are worried about losing their power, fearing losing the power leads to aggressiveness and violence and this circle goes on in the society as a whole. According to Franco (1970), in the La ciudad y los perros, the high school as a whole, along with its ruling system, is the symbol of the society Llosa wishes to describe. The groups and parties shaped at the school are the symbols of different groups of the society, and the rules governing the school stand for the laws governing the society.

A typical example of Violence in Llosa's works has been manifested in the suppression and murder of the Mirabal sisters by the Trujillo's regime. In early November 1960, General Trujillo, the Dominican president, stated that his country encountered two problems: the church and the Mirabal sisters. These four sisters were born in the Mirabal family. Their father was a successful businessman who provided for a luxurious life for his daughters. Inspired by her uncle, one of those sisters joined the anti-Trujillo movement and studied law at the university. However, since she rejected sleeping with a goat, she could never obtain her degree from the university upon Trujillo's instruction. The other sisters joined the Minerbal and were able to unite a significant number of Trujillo's opponents. This union led to the formation of the June 14 Movement in the Dominican Republic, which attempted to overthrow Trujillo. Trujillo put the husbands of Mirabal sisters into prison and tortured them to prevent the wives from carrying on with their political activism, but he failed. On the evening of November 25, 1960, upon returning home from visiting their husbands in prison, Patria, Minerva, and Maria Teresa were severely beaten and then suffocated by some unknown people. Fabricating the scene of an accident, the assailants threw their car into a valley. From the historians' perspective, the murder of Mirabal sisters was a turning point leading to Trujillo's decline because Dominican people never believed the stories fabricated about their death in a driving accident (Llosa 2001a, 161).

In fact, the murder of Mirabal sisters is the symbol of violence against women in Latin American societies. Violence from the top - on behalf of the regime against the citizens violence from the bottom - in the interaction between community members - is cited in Llosa's works. An example can be found in the tension between the social groups and the government in the tram workers' strike explained in the Novel, Conversación en La Catedral. Of course, this strike was not political in nature; instead, they called for an increase in their wages. This strike, planned by the university students' secret team and the workers' circle, was suppressed by the regime officers as violently as possible. "The police have pulled the signs off the wall of San Marcos, and have erased the letters that said up the strike and down with Odria. No students were to be seen on the campus. Policemen were clustered together across from the founders' chapel, two patrol cars parked on the corner of Azangaro, a troop of assault guards in the neighboring vacant lots" (Llosa 2005, 154).

\section{The Liberating Communism and Novice Communist}


The pervasive presence of dictatorship in Latin America made most people think that Communism would be the best way to bring them freedom and democracy. The most crucial armed group against the ruling regime, which Llosa highlights in his works, were communists. In the 1950s and 1960s, Llosa was a proponent of the left-leaning ideology. In those days, the leftist ideology was very attractive for most Latin American people, and the victory of the Cuban revolution (1959) made other nations believe that success is possible for them. Before the Cuban revolution, thinking about revolutionary actions was fanciful and unattainable, something just utopian, not ever possible in a country like Peru. "History after moving for so many years like a tortoise, have suddenly become meteor, thanks to Cuba" (Llosa 2007b, 20). Or, as Llosa mentioned in La historia de Mayta: "Until then the idea of revolution was romantic and remote to us, something we took more as an academic idea that could never become a reality in countries like ours" (Llosa 1991, 145).

In the Novel, La historia de Mayta, a real communist movement that happened in Peru has been portrayed: "No remorse, not anything even like it, says Blacquer. It was Cuba. The Cuban revolution broke through taboos. It killed that superego that ordered us to accept the dictum that' condition isn't right,' that the revolution was an interminable conspiracy. With Fidel's entrance into Havana, the revolution seemed to put itself within reach of anyone who would dare fight" (Llosa 1986: 144). Llosa presents Mayta as a person who devoted his entire life to revolution and is active in all parties and groups shaped in the 1950s. He got separated from Communism due to differences in opinion. He thought that Guerrilla fighting is the best option for changing the circumstances. He believed Guerrilla fighting united the real revolutionists because the revolutionary actions represented the sole remedy for the problems rooted in political dysfunction. This vicious circle would be demolished with effort and would be eyeopening for the opponents (Llosa 1986, 117).

Finally, in the revolutionary scale, Mayta and his team managed to control one of the small villages of Peru for a few hours. They, however, were defeated and arrested by the police. In the 1970s, Llosa lost his faith in revolution and changed his mind about the idea that strikes and violence against the existing political system could improve the situation and lead to financial and social reform. This point is clearly illustrated at the end of the novel: "It may turn out that the great revolution of those years wasn't any of the ones you think it was, Juanita interrupts me. Because- have all these murders and attacks produced anything positive? Violence only breeds violence. And things haven't changed, have they? There is more poverty than ever, here, out in the country, out in the mountains, everywhere" (Llosa 1986, 51).

In the Novel Travesuras de la niña, Llosa shows how the communist movement is paving the way for the revolution out of Peru's borders. The founder of this movement is a person called Paul, who was exiled from Peru because of organizing the strike of San Marcos University in Oderia's era: "His had to do with preparations for the revolution that would make Peru the second Socialist Republic of Latin America" (Llosa 2007b, 18).

Cuban government awarded 100 scholarships to the leftist, revolutionary party to offer ideological and military training to Peruvian girls and boys. These young girls and boys came from various social classes and ethnic groups. After receiving military training, they were sent to Peru to do such guerilla actions as stealing the gunpowder of a mine, exploding a bridge, and even planting bombs in a hotel. However, all these violent actions led to the establishment of a military government in Peru, instead of improving the situation: "El Comercio and La Prensa, and Apristas and Odristas now allied against the government, were accusing Belaunde Terry of weakness in the face of the Castrista rebels, and even of secret complicity with the insurrection. The government had made the army responsible for suppressing the rebels" (Llosa 2007b, 50). Through suppressing communist parties and forbidding their activities, Oderia took control over the situation. After gaining power, Oderia started to arrest the opposition party members, including Communists and Apristas. However, the communists continued their actions illegally and secretly: "I can see now why 
you're so worried about security, Senator Vivero told Washington. Because you're all the redtails left in the country and if the cops come and arrest us, communism will disappear in Peru" (Llosa 2005, 135).

However, those communists, despite what they pretend, lacked comprehensive knowledge of Marx's ideas and society's political situation. They were like blind people who imitate everything and repeat what they hear without thinking about their meaning. This fact was revealed in their statements for the workers; the workers did what they were requested to do without understanding what was said in the speech. That is why they did not expose the location of foreign engineers. "If even one had pointed a finger or nodded his head toward the water tank, shortly agreed, they'd have given us a revolutionary trial and we'd be in paradise by now, isn't that right, Beli?" (Llosa 2007a, 117). The same was right about the people of the city. When the militia attacked the city and punished the accused individuals, the people who gathered did not understand anything about what the militia said and believed; the people only were frightened and embarrassed: "The townspeople seemed to listen more than they really listened, to understand more than they really understood" (Llosa 2007, 55). According to Kristal et al. $(2012,5)$, Llosa abandoned his interests in socialism by the 1980s, and became an outspoken advocate of market economy and democracy. His political allegiances had shifted from Fidel Castro to Margaret Thatcher. The mentioned changes can be observed in the Novel, Lituma en los Andes, where the violence from the bottom by the militia was envisaged.

\section{Corruption}

Corruption can be defined as "the abuse of political power for personal gain." According to Morris and Blake $(2010,1)$ the first thing that often comes into mind with the Latin American politics is corruption. Every day when you flick through the newspaper pages or listen to the news of this region, you will frequently face scandals of former presidents, senators, politicians, and so on. In most of his works, Llosa attempts to disclose the widespread corruption in governmental bureaucracy and even among ordinary people. The interesting point here is that corruption is to be expected under an authoritarian regime, where those in power enjoy impunity and are sheltered from public criticism (Whitehead $2000,107)$. Llosa illustrates the lack of precise distinction between people's properties and the government's properties in Trujillo's regime in the novel La fiesta del chivo. Llosa states that after the United States imposed sanctions against Trujillo, financial chaos pervaded Dominica. Trujillo's economic counselors offered him to put the burden of his own companies' losses upon the government because public assets of a country belong to the ruler in dictatorial regimes. (Llosa 2001a, 136).

Another example of Trujillo's regime's financial corruption that Llosa mentions in La fiesta del chivo relates to using public properties for giving gifts to people to get their consent and support. This money was given to people to prove that Trujillo appreciates their loyalty. The fact of the matter is that dictators enjoy having power more than having money. The only way to enhance power and preserve it is to purchase people's loyalty by giving them money and gifts (Llosa 2001a, 147).

In the Novel Conversación en La Catedral, Llosa shows that corruption flows at all levels of government bureaucracy, and the prevalence of corruption made it seem natural: “And besides, it wasn't just Mr. Lozano who took advantage, Ambrosio said. That pair said that on the force everybody on the list took bribes in some way, from the highest down to the lowest. That's why Ludovico's great dream was to become a regular. You mustn't think that everybody's as honest and decent as you are, sir" (Llosa 2005, 338).

Through showing the way people obtain the high positions in the governmental structure in Trujillo's time in La fiesta del chivo, Llosa portrays the phenomenon of clientelism across Latin America in general and in the Dominican Republic in particular. Llosa shows that assigning people to high positions is not based on their competences and capabilities in this era. Instead, they are assigned with the direct order of Trujillo to preserve his interests. “He hadn't earned his 
strips the way they had, by studying, going through the academy, living in barracks, sweating to rise through the ranks. He had his as payment for the undoubtedly dirty services he had rendered to justify his appointment as the all-powerful head of the Military Intelligence Service" (Llosa 2001a, 43).

Another aspect of corruption of this era is visible in the recruitment of legal experts to modify the laws to legitimize the decisions made by the dictator: "He had also composed the most important institutional and ordinary laws, and written almost all the legal decisions adopted by the Congress to legitimize the need of the regime. There was no one like him forgiving, in parliamentary speeches filled Latin phrases and quotations that were often in French, the appearance of juridical necessity to the most arbitrary decision of the Executive, or for refuting, with devastating logic, every proposal that Trujillo disapproved of" (Llosa 2001a, 133).

Machintosh $(2011,76)$ showed that the Novel Quién mató a Palomino Molero? Implicitly refers to the distinctions and confrontations of race and class. Fremont $(1987,4)$ argued that the novel envisaged a set of complex conflict and tension. This conflict and tensions exist between races, classes, and sexes. Those tensions are the principal barriers to solving the mystery of the murder and color our guilt and innocence concepts. The most crucial issue that Llosa deals with relates to the corruption of the judicial system. When the officers were investigating Palomino's death, they faced some questions raised by people. These questions revealed that the people did not trust the robustness of the judicial system: "That you're covering up because the murderers are big shots" (Llosa 1986, 20). Or "Well? You going to solve this one, or are you going to cover things up to protect the big guys?" said one of the airmen" (Llosa 1986, 30). In this Novel, Llosa expresses that in a society that is founded upon inequality, justice cannot be achieved. The detectives faced some barriers while they attempted to disclose the secret of this murder. The biggest obstacle was the colonel of the army's air force, who even did not allow them to interrogate the soldiers: "If that damned Colonel Mindreau cooperated, things would be easier. He had to have information, files, the power to interrogate the base personnel, and if he wanted to help them, they'd find plenty of clues and then catch the sons of bitches." (Llosa 1986, 18). Or on another occasion, he states that "But Colonel Mindreau isn't helping us. He won't let me question Palomino Molero's buddies. They must know something. We can't get anywhere, and it's his fault. But sooner or later, the truth will come out" (Llosa 1986, 18). The most eye-catching point of this novel comes at the end of the story; disclosing the secret of the murder does not lead to a good ending for the detective: "You were so eager to solve the mystery of Palomino Molero. Well, now it's solved, and I did it for you. So, what do we get for our trouble? You're transferred to the mountains, far from your heat and your people. They'll probably find a worse hole for me" (Llosa 1987, 115).

In the Novel, The Time of the Hero, Llosa portrayed another aspect of corruption in the official ranks, namely the unwillingness to unveil the details of one of the students' death. On the day of military maneuver in the military school, one of the students was killed by gunshot. Looking at the bullet strike point, the school officers learned that it could not be an accident; instead, someone had deliberately shot the student to kill him. The school officers tried to cover up this murder and represent it as an accident because unveiling the killing details would harm the school's fame and credibility. "All right, you'll read an Order of the Day at the first formation. Now listen closely. The officers and the student body deeply lament the accident, which has cost the cadet's life. That's the way it should sound. Be sure to emphasize that it was due to his own negligence. Don't leave the slightest doubt about that" (Llosa 1966, 190). Also, the necessary arrangements made to prevent the reality from being revealed at the funeral were expressed accordingly (Llosa 1966, 190-191).

\section{The Role of the United States}

Since the Monroe Doctrine was initiated, Latin America has been treated as a U.S. backyard and a monopole sphere of influence (Cottam 1994). Sometimes the U.S interference was done using direct military intervention like in Panama (1989), 
sometimes with the covert operation, military coups (Chile in 1973), or economic incentives. It led to this perception that the United States as a superior power can do anything.

In La fiesta del chivo, Llosa elaborates the United States' role in Trujillo's coming to power and long-ruling. Although the United States became aware of Trujillo's entire secret details through the CIA and knew about all cases of human rights violations, the U.S. did not take any action and was indifferent to these violations. The reason is that because, at that time, the U.S. believed Trujillo's tyrant dictatorship was the guardian of U.S. interests in the Caribbean region. In fact, Trujillo's dictatorship was a powerful barrier against the spread and development of Communism, which is a vital issue for the U.S.Gradually, with the change of political circumstances and due to some other factors. However, the U.S.'s posture changed. In this regard, the US President John F. Kennedy planned for deposing Trujillo, and for this purpose, the president made use of the CIA. "The United States, uneasy about Trujillo's excesses ever since the attempt on the life of the Venezuelan President, Romulo Betancourt, wanted to get rid of him; at the same time, they wanted to be sure he would not be replaced by the second Fidel Castro" (Llosa 2001a, 365).

After Trujillo's scandals, such as the murder of Mirabal sisters in 1961, the U.S. implicitly indicated its agreement to hatch a plot against him. Their most crucial assistance to that effect was providing armaments. A large number of ministers, senators, civilian officials, as well as high-ranking army officers who were aware of the plot against Trujillo, were ready to cooperate in different endeavors such as political reform, removing the last traces of Trujilloism, opening up the political environment and shaping militarycivilian Junta which was supposed to guarantee the peace and order of Dominica with the support of the United States, prevent the expansion of Communism, and hold a free election (Llosa 2001a). Trujillo's regime epitomized the governments in almost all Latin American countries that suffered from the United States' interference. The most important effect of this interference is people's inability to make decisions about the country's domestic affairs because this interference denies people influence over their destiny and puts it in the hands of a foreign power. Consequently, the possibility of achieving stability and democracy will fade away in such countries. This notion has been demonstrated in different ways in other Llosa's novels, as well.

In the Novel, Conversación en La Catedral, Llosa briefly points to the United States' interference in his country's affairs. When Don Cayo occupied San Marcos University without informing the minister of public order, he faced a significant amount of objection. Colonel Espina told him this action results in the dissatisfaction and dissent of foreign countries; the current ruling government (in Peru) would not be pleased about this situation because many countries have not yet formally recognized it. "The United States has recognized us and that's the important things, Bermudez said. Don't worry about the President, Unplander. I talked to him last night before I made my move" (Llosa 2005, 108).

Another aspect of the United States' interference in Latin American countries was giving loans and grants to the governments supporting the U.S. policies. Countries that comply with the United States' purposes can enjoy the U.S. assistance and support by running a superficial election, even if they are not democratic. In fact, this is the U.S. instrument by which it can bring to power proAmerican governments across the region. In Conversación en La Catedral, Llosa demonstrates this idea in a conversation between Don Fermin and Emilio Arevalo: "It's all a matter of Loans and credit, Don Fermin said. The United States is ready to help a government that maintains order; that's why they backed the revolution. Now they want elections, and we have to give them what they want" (Llosa 2005, 119). "The gringos believe in formalities, we have to understand them, Emilio Arevalo said. They're happy with the General and all they ask is that democratic forms be preserved. With Odria as an elected president, they'll open their arms to us and give us all the credit we need" (Llosa 2005, 120).

Another manifestation of America's interference, as pointed by Llosa, is 
establishing different research centers to expand neocolonialism in Latin America. In the Novel, El hablador, Llosa mentions one of these centers in the Amazon area called the Summer Institute of Linguistics. The purpose of this center is to help Indians learn English and read the Bible. "What exactly is the purpose of the Institute? According to its enemies, it is a tentacle of American imperialism which, under cover of doing scientific research, has been engaged in gathering intelligence and has taken the first steps toward a neocolonialist penetration of the cultures of the Amazonian Indians" (Llosa 1989, 56). The opponents of this plan challenge it and pose the question, how would it be possible for the Indians to learn English and speak it before learning Spanish? Generally, it could be said that Llosa, just like ordinary people, was sensitive to his native country's independence from foreign powers. Besides showing the dependent nature of all Latin American countriesespecially Peru, his own country, Llosa highlights the critical fact that decisionmaking, implementing the policies, and even the cultural schemes of these countries are controlled and influenced by foreign powers.

\section{Conclusion}

Large parts of Llosa's works deal with describing and criticizing the socio-political situation of his own country. He believes citizens should not be indifferent to their society's affairs; instead, he considers active participation in different community matters is one of the citizens' responsibilities. This study reviewed the most pivotal points criticized by Llosa regarding his time's sociopolitical situation and the problems existing in the developing countries. For Llosa, writing has always been a weapon against despair and tyranny, and his work has always been an attempt to counter the waves of destructive political and intellectual currents. He has been a proponent of individual liberties and democracy in Latin America, and his harsh criticism of political officials has created enemies for him, both among socialists and conservatives. The first and the most critical point criticized by him relates to the totalitarianism in Latin America's countries in general and his own country, Peru, in particular. Dictatorial governments, which have ruled over this region for many years and turned into dogmatic military regimes since the 1950s, greatly influenced the region's political and social developments. One of the most essential effects of authoritarian governments of that time was that they had prevented the freedom of expression. Therefore, literature was used as an instrument for expressing the opinions, pains, and suffering of the people.

Of the characterization of dictatorial regimes and their political impacts in Llosa's works, mention must be made of the harsh suppression of the opponents, torture, escalation of the level of violence, people's frustration and disappointment, systematic and pervasive corruption, the US intervention, and identifying Communism as the sole savior ideology. Regarding social consequences, the dictatorial regimes affect people's social and private relations; they can even influence the relationship between the father and his child and ruin the love between them. Generally, Llosa attempts to show that dictatorship is destructive because it destroys civilization, symbiosis, and peace in society. In Llosa's opinion, dictatorship, either political or religious, results in the reversion of history and relegates people to barbarian time. Even the most elementary problems of human beings could not be solved. Thus, through criticizing the dictators, Llosa attempts to fight against such regimes and defend democratic goals. This hatred of dictators is rooted in Llosa's personal experiences.

\section{References}

Burke, K. (1973). Literature as equipment for living. The philosophy of literary form, 293-304.

Castro-Klarén, S. (1989). Mario VargasLlosa. Latin American Writers. Eds. Carlos A. Solé and Klaus Müller-Bergh. New York: Charles Scribners Sons, 3.

Chang-Rodríguez, R., \& Riobó, C. (Eds.). (2020). Talking Books with Mario Vargas 
Llosa: A Retrospective. University of Nebraska Press.

Cueto, A. (2012). "Reality and rebellion: An overview of Mario Vargas Llosa's literary themes." In The Cambridge Companion to Mario Vargas Llosa, ed. by Kristal. Efraín King. John, 9-22, Cambridge: Cambridge University Press.

De Castro, J. E. (Ed.). (2014). Mario Vargas Llosa. Salem Press, a division of EBSCO Information Services, Incorporated.

Foley, A. (2008). Power, Will and Freedom: Mario Vargas Llosa's The Feast of the Goat. JLS/TSW, 24(1), 1-31, DOI: $10.1080 / 02564710701789008$.

Franco, J. (1967). The modern culture of Latin America: society and the artist. Pall Mall Press.

Fremont, H. (1987). Erato, (5/6), 4-4. Retrieved June 25, 2020, from www.jstor.org/stable/27541250

Gorham, E. (2005). TEACHING POLITICAL JUDGMENT THROUGH LITERATURE: Lessons from Hannah Arendt and Mario Vargas Llosa. Soundings: An Interdisciplinary Journal, 88(3/4), 265291. Retrieved June 25, 2020, from www.jstor.org/stable/41179127

Ibrahim, S. G., Liman, A. N., \& Okoroafor, P. A. (2014). Political and economic frustration in northern Africa: A precipitating force for the emergence of the Arab Spring and Revolution. Online Journal of African Affairs, 3(2), 26-36.

Kristal, E. \& King, J, eds. (2012). The Cambridge Companion to Mario Vargas Llosa. Cambridge: Cambridge University Press.

Kristal, E. (2011). "The total novel and the novella: Conversación en La Catedral and The Cubs". In The Cambridge Companion to Mario Vargas Llosa, ed. by Kristal. Efraín - King. John, 37-48. Cambridge: Cambridge University Press. DOI:10.1017/CCOL9780521864244.005
Kristal, E. (1998). Temptation of the Word: The Novels of Mario Vargas Llosa. Vanderbilt University Press.

Llosa, M. V. (2005). Conversation in the Cathedral, Translated from Spanish to English by Gregory Rabassa, Harper and Row: New York.

Llosa, M. V. (2007a). Death in the Andes, Translated from Spanish to English by Edith Grossman, Farrar, Straus and Giroux: New York.

Llosa, M. V. (2007b). The Bad Girl, translated from Spanish to English by Edith Grossman, Farrar, Straus and Giroux: New York.

Llosa, M. V. (2001a). The Feast of the Goat, Translated from Spanish to English by Edith Grossman, Farrar, Straus and Giroux: New York.

Llosa, M. V. (1986). The Real Life of Alejandro Mayta: A Novel, Translated from Spanish to English by Alfred MacAdam, Farrar, Straus and Giroux: New York.

Llosa, M. V. (1989). The Storyteller, Translated from Spanish to English by Helen Lane, Farrar, Straus and Giroux: New York.

Llosa, M. V. (1966). The Time of the Hero, Translated from Spanish to English Lysander Kemp, Farrar, Straus and Giroux: New York.

Llosa, M. V. (2008). The War of the End of the World, Translated from Spanish to English by Helen Lane, Farrar, Straus and Giroux: New York.

Llosa, M. V. (1987). Who Killed Palomino Molero? Translate from Spanish to English by Alfred MacAdam, Farrar, Straus and Giroux: New York.

Llosa, M. V. (2001b). Why literature? At: https://genius.com > M > Mario Vargas Llosa.

Llosa, M. V. (19910. A Writer's Reality, Edited, With an introduction by Myron I. Lichtblau, New York: Syracuse university press. 
Marcus-Delgado, J. (2004). Demonic Power and Political Discourse in Mario Vargas Llosa's "La fiesta del chivo". Confluencia, 19(2), 125-133. Retrieved June 25, 2020, from www.jstor.org/stable/27922999

Menton, S. (2000). "La fiesta del Chivo." World Literature Today 74,3: 676-676. doi:10.2307/40156034

Montes, C. (2011). "The Imaginary in the City and the Dogs of Mario Vargas Llosa." Chilean magazine of literature Online version, 80, 65-86.

Morris, S. D. (2004). "Corruption in Latin America: an empirical overview." Secolas Annals 36, 74-92.

Morris, S. D., \& Blake, C. H. (Eds.). (2010).Corruption \& politics in Latin America: national and regional dynamics. Boulder, CO: Lynne Rienner Publishers.

The Guardian. (2002). Watching the dictators. At: https://www.theguardian.com/books/2 002/apr/07/fiction.features

The New York Times Magazine. (2018). The Elder Statesman of Latin American Literature, and a Writer of Our Moment. At: https://www.nytimes.com/2018/02/20/ magazine/the-elder-statesman-of-latinamerican-literature-and-a-writer-of-ourmoment.html

The New York Times. (2010). Vargas Llosa Takes Nobel in Literature. At: https://www.nytimes.com/2010/10/08/ books/08nobel.html

Torres-Rivas, E. (1999). "Epilogue: notes on terror, violence, fear and democracy." Societies of Fear: The Legacy of Civil War, Violence and Terror in Latin America, 285300.

Whitehead, L. (2000). "High-level political corruption in Latin America: a transitional phenomenon." Combating corruption in Latin America, 107-129.

Wolff, A. B. (2006). Rewriting Trujillo, Reconstructing a Nation: Dominican
History in Novels by Marcio Veloz Maggiolo, Andrés L. Mateo, Viriato Sención, and Mario Vargas Llosa. 